\title{
A Rapid Method for Measuring Seed Protein Content in Cowpea (Vigna unguiculata (L.) Walp)
}

\author{
Yuejin Weng', Ainong Shi ${ }^{*}$, Waltram Second Ravelombola ${ }^{1}$, Wei Yang ${ }^{1}$, Jun Qin ${ }^{1}$, Dennis Motes ${ }^{2}$, \\ David Octor Moseley ${ }^{3}$, Pengyin Chen ${ }^{4}$
}

${ }^{1}$ Department of Horticulture, University of Arkansas, Fayetteville, AR, USA

${ }^{2}$ Vegetable Research Center, University of Arkansas, Alma, AR, USA

${ }^{3}$ Department of Crop, Soil and Environment, University of Arkansas, Fayetteville, AR, USA

${ }^{4}$ Fisher Delta Research Center, College of Agriculture, Food and Natural Resources, University of Missouri, Portageville, MO, USA

Email:*ashi@uark.edu

How to cite this paper: Weng, Y.J., Shi, A., Ravelombola, W.S., Yang, W., Qin, J., Motes, D., Moseley, D.O. and Chen, P.Y. (2017) A Rapid Method for Measuring Seed Protein Content in Cowpea (Vigna unguiculata (L.) Walp). American Journal of Plant Sciences, 8, 2387-2396.

https://doi.org/10.4236/ajps.2017.810161

Received: August 14, 2017

Accepted: September 10, 2017

Published: September 13, 2017

Copyright (c) 2017 by authors and Scientific Research Publishing Inc. This work is licensed under the Creative Commons Attribution International License (CC BY 4.0).

http://creativecommons.org/licenses/by/4.0/

\begin{abstract}
Cowpea (Vigna unguiculata (L.) Walp), a legume crop that is grown in the worldwide, provides beneficial proteins for human consumption and animal feeding. In comparison, Rapid $\mathrm{N}$ analyzer as traditional method, has been widely used to measure protein content through the percentage of total nitrogen in the seed's grounded powder. Near-Infrared Reflectance (NIR) has commonly been used to measure protein content in soybean seeds using whole grain without the need of seed grinding, which makes it possible to obtain fast results at a lower cost-per-analysis than the traditional combustion method. The specific objective of this study is to test a rapid method for measuring cowpea seed protein content by the NIR analyzer comparing to the traditional rapid $\mathrm{N}$ analyzer. A total of 240 cowpea genotypes were used in this study, including six seed coat colors, black, blackeye, browneye, cream, pinkeye, and red with 40 cowpea genotypes. The results showed that a linear relationship exists between the NIR analyzer and the Rapid N analyzer in the six different color groups. The correlation efficiency $(r)$ between the seed protein contents from NIR and Rapid N was higher for pinkeye seed $(r=0.867)$, blackeye $(0.771)$, cream (0.729), browneye (0.700), and red (0.623), respectively, but lower for black seeds, indicating that the NIR analyzer can be used to measure protein content for cowpea seeds with the five types of seed coat except black. Overview, the cowpea seed protein content measured from the NIR analyzer showed a little higher seed protein content. A series of regression models with different seed coat color have been built to adjust to protein content of color-
\end{abstract}


ful cowpea seeds from the NIR analyzer. But, it is not recommended to use for black color seeds due to a very low correlation efficiency (r) value with 0.184 .

\section{Keywords}

Cowpea, Seed Protein Content, Protein Measurement Method, Rapid N Analyzer, Near-Infrared Reflectance (NIR), Vigna unguiculata

\section{Introduction}

Cowpea (Vigna unguiculata (L.) Walp), a legume crop that is grown worldwide, provides beneficial proteins for human consumption, animal feeding, and the environment [1]-[6]. The largest acreage to grow cowpea is in Africa, with Nigeria and Niger predominating. Besides Africa, Brazil, West Indies, India, United States, Burma, Sri Lanka, Yugoslavia, and Australia also have large cowpea production [3] [5]. Dry seed production is estimated at 1.24 million tons annually in the world. Cowpea is grown as a food crop, but also as a canned vegetable product (both for the greens and the green peas), a cover crop, and as fodder. Cowpea primarily provides protein, soluble sugar, amino acids, vitamins, and minerals [1] [7] [8].

The greatest value of cowpea seed is its rich protein content as traditional food to customers, in particular, it can provide sources of protein to improve the nutritional status of resource-poor subsistence family in developed countries in the world [9] [10]. Carnovale et al. [1] compared protein contents from cowpea commercial cultivars and from International Institute of Tropical Agriculture (IITA) improved lines and found that both sources had similar seed protein content (22.4\% for commercial and $21.9 \%$ for IITA). Itatat et al. [11] reported that the seed protein content ranged from $20.57 \%$ to $24.95 \%$ among eleven cowpea genotypes. However, Afiukwa et al. [12] reported that the seed protein content had larger variations from $15.06 \%$ to $38.5 \%$, with a mean of $25.99 \%$ in cowpea dry seeds.

There are several ways to measure protein concentration in agricultural products, and each of them has its own advantages and disadvantages [13]. The Kjeldahl method is a classical method for the quantitative determination of organic nitrogen in chemical substances like ammonia. It was developed in 1883 by a brewer Johann Kjeldahl [14]. A sample is digested with a strong acid (sulfuric acid) so that it releases nitrogen which can be determined by a suitable titration technique. The amount of protein present is then calculated from the nitrogen concentration of the sample. Because the Kjeldahl method does not measure the protein content directly, a conversion factor $(\mathrm{F})$ is needed to convert the measured nitrogen concentration to a protein concentration. A conversion factor of 6.25 (equivalent to $0.16 \mathrm{~g}$ nitrogen per gram of protein) is used for many applications, however, this is only an average value, and each protein has a different conversion factor depending on its amino-acid composition. A number of improvements have been made to speed up the process and to obtain more accu- 
rate measurements. New techniques for protein measurement are becoming more popular than the chemical Kjeldahl method due to its complex three steps: digestion, neutralization, and titration. Absorbent UV light at $280 \mathrm{~nm}$ is other different method for protein measurement. Bradford colorimetric assay based on the interaction between Coomassie brilliant blue and the arginine and aromatic residues. Rapid N, a nitrogen/protein analyzer which presents the fast, safe, and environmentally friendly alternative to the classical method, has been widely used to measure protein content through the percentage of total nitrogen in the seeds' grounded powder. With the high temperature and pure oxygen condition, nitrogen is liberated by combustion. The nitrogen is then isolated from other combustion products. A thermal conductivity detector measures the nitrogen content in the sample. Protein content is determined by the combustion method and a conversion factor of 6.25 was used to convert total nitrogen to protein.

Near-Infrared Reflectance (NIR), a spectroscopic method that sets new standards in protein analysis according to the near-infrared region of the electromagnetic spectrum (from about 700 - $2500 \mathrm{~nm}$ ), has commonly been used to measure protein content in whole grain, such as soybean seeds, without the demand of grinding. It is possible to achieve fast, no-damage, and low cost-peranalysis results compared to the traditional method of combustion for total nitrogen when applied to determine protein content [15]. The DA 7250 NIR analyzer is the third generation diode array NIR instrument from Perten Company, Sweden, designed specifically for analysis in agricultural industries. Okonya and Maass [3] (2014) successfully used Near Infrared Spectrometry to determine the crude protein content of leaves from six cowpea genotypes, and found that the protein content in leaves in these genotypes averaged $30 \%$.

In order to test for an accurate, reliable, rapid, non-destructive, and inexpensive method to measure protein content in cowpea, the specific objectives of this study were to evaluate the NIR methods of measuring cowpea seed protein content and to determine the possible relationship with classical protein measurement methods.

\section{Materials and Method}

\subsection{Cowpea Seed Materials and Measuring}

A total of 240 cowpea genotypes including 214 USDA GRIN cowpea germplasm accessions and 26 Arkansas cowpea breeding lines were used in this study, including six seed coat colors, black, blackeye, browneye, cream, pinkeye and red with 40 cowpea genotypes each. Experiment was conducted in two locations at University of Arkansas experiment station in Fayetteville (FY) and Alma, Arkansas, USA in 2016. The randomized complete block design (RCBD) was used in each location with three replicates. Each plot consisted of planted in a single 15 -feet row length and 3-feet width, where there were 16 to 20 plants grown with 6-inch distance between two plants. The plots were maintained without any pesticides or herbicides during the growing season. Cowpea seeds were harvested by 
plot individually. After cleaning and drying for a few of weeks, 100 grams of whole grain was collected and prepared to measure protein content using INR DA7250. After measuring for protein content by NIR DA7250, $5 \mathrm{~g}$ each sample was ground by coffer grinding (Hamilton Beach) for 1 minute. $0.11-0.15 \mathrm{~g}$ of ground flours were passed through sieve 25\# (bore diameter $850 \mu \mathrm{m}$ ) and prepared to protein content measure by Rapid $\mathrm{N}$ method.

Cowpea has a rich diversity of seed coat color, including black, brown, blue, cream, green, grey, mix (two or more colors), and purple, red, tan, and yellow color. In this study, six most popular cowpea seed color types in market: black, blackeye, browneye, cream, pinkeye and red color were used with 40 accessions each (Figure 1). Black color: Seeds dry down to an intense black color and have no noticeable "eye". An example of black color is the released cultivar "Ebony"; Blackeye: The seeds come out of the pod clean and free, the white hilum is surrounded by black, which shows excellent market type; Browneye: The white hilum is surrounded by brown or dark brown color; Pinkeye: These are the more popular color of cowpea seed for consumption in markets, their white hilum is surrounded by pink color or light-red; Cream: Seeds of these types are generally cream colored and have no noticeable "eye", it looks like soybean seed, but smaller size; Red color: Seeds of these types have a red colored coat and have no noticeable "eye". The advanced breeding line "07-303" serves as an example of red color. Therefore, an objective of this study is to investigate whether cowpea seed coat color affects the measurement of protein content by NIR.

In this experiment, two soybean cultivars, "Osage" and "Ozark" were used as controls. NIR analyzer DA7250 has been used in soybean for measuring seed protein content and has been a good method regarding specificity and steadiness to measure whole grain protein content. Both "Osage" and "Ozark" showed a protein content of $42.82 \%$ - $43.54 \%$ and $39.41 \%$ - $40.56 \%$ in four time measurements, respectively. Repeated test showed that NIR analyzer method had the specificity and steadiness for protein content measurement of grain seeds.

\subsection{Equipment of Cowpea Seed Protein Content Measurement}

For NIR method, total protein content of the cowpea seeds was measured by the third generation diode array NIR instrument DA 7250 NIR analyzer, produced in Perten Company, Sweden. In contrast, same sample with powder was measured by analyzing the percentage of nitrogen by combustion using Rapid N III instrument, which is a product from the Elementar Company, a world's leading

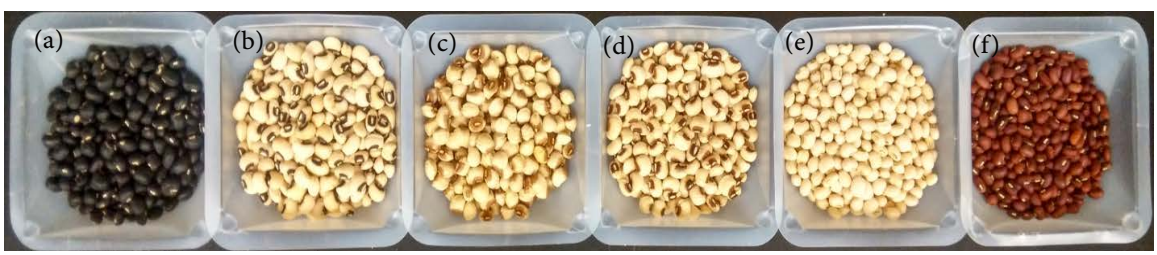

Figure 1. Cowpea seed coat color pattern: (a) Black seed; (b) Blackeye seed; (c) Browneye seed; (d) Cream seed; (e) Pinkeye seed; and (f) Red seed. 
manufacturer of analytical instrumentation in Germany. The equipments for both methods were provided at the laboratories of Department of Crop, Soil and Environment, University of Arkansas, USA.

\subsection{Data Collection and Analysis}

Analysis of cowpea seed protein data was performed by analysis of variance (ANOVA) using the general linear models procedure of JMP Genomics 7. The relationship between the Rapid N III and NIR method was evaluated by the correlation coefficient $(\mathrm{r})$.

Calculations of the correlation coefficient $(r)$ are usually used to compare the results of two methods of measurement of the same substance [16]. The result is usually expressed as a regression line $\mathrm{Y}=\mathrm{aX}+\mathrm{b}$, a formula in which " $\mathrm{a}$ " is the slope of the line called regression coefficient, and " $b$ " is the intercept on the ordinate. Often, " $r$ " the correlation coefficient is calculated. If " $r$ " and "a" are close to unity and " $b$ " close to zero, the two methods are said to agree with each other. The value of " $r$ ", ranging from 0 to 1 , is usually a matter of judgment.

\section{Results and Discussion}

In this study, a total of 240 cowpea genotypes including 214 cowpea germplasm accessions and 26 breeding lines were measured their seed protein contents by the NIR and Rapid N method (Table 1 and Figure 2). Overview, the analytical results showed significant variability for all the attributes and the values ranged

Table 1. Cowpea seed protein contents in six seed coat colors by two measurement methods.

\begin{tabular}{|c|c|c|c|c|c|c|c|c|c|c|}
\hline $\begin{array}{l}\text { Seed coat } \\
\text { color }\end{array}$ & Type & $\mathbf{N}$ & Mean & Std Dev & Min & $\operatorname{Max}$ & Range & Variance & Std Err & $\mathrm{CV}$ \\
\hline \multirow{2}{*}{ Black } & Rapid N III & 40 & 25.98 & 1.52 & 23.44 & 29.69 & 6.25 & 2.31 & 0.24 & 5.85 \\
\hline & NIR DA 7250 & 40 & 34.23 & 1.17 & 31.84 & 36.71 & 4.87 & 1.36 & 0.18 & 3.41 \\
\hline \multirow{2}{*}{ Blackeye } & Rapid N III & 40 & 25.76 & 1.89 & 21.03 & 29.48 & 8.45 & 3.58 & 0.30 & 7.34 \\
\hline & NIR DA 7250 & 40 & 34.08 & 1.63 & 30.56 & 37.75 & 7.19 & 2.67 & 0.26 & 4.79 \\
\hline \multirow{2}{*}{ Browneye } & Rapid N III & 40 & 25.77 & 1.52 & 22.56 & 28.75 & 6.19 & 2.31 & 0.24 & 5.90 \\
\hline & NIR DA 7250 & 40 & 34.13 & 1.54 & 29.63 & 37.29 & 7.66 & 2.38 & 0.24 & 4.52 \\
\hline \multirow{2}{*}{ Cream } & Rapid N III & 40 & 26.26 & 1.75 & 21.86 & 28.91 & 7.05 & 3.06 & 0.28 & 6.66 \\
\hline & NIR DA 7250 & 40 & 34.64 & 1.57 & 31.26 & 37.69 & 6.43 & 2.47 & 0.25 & 4.53 \\
\hline \multirow{2}{*}{ Pinkeye } & Rapid N III & 40 & 24.85 & 1.89 & 21.18 & 28.20 & 7.02 & 3.57 & 0.30 & 7.60 \\
\hline & NIR DA 7250 & 40 & 34.27 & 2.12 & 28.76 & 37.60 & 8.84 & 4.47 & 0.33 & 6.17 \\
\hline \multirow{2}{*}{ Red } & Rapid N III & 40 & 24.59 & 1.96 & 21.34 & 29.08 & 7.74 & 3.85 & 0.31 & 7.98 \\
\hline & NIR DA 7250 & 40 & 32.82 & 1.62 & 29.46 & 35.61 & 6.15 & 2.62 & 0.26 & 4.93 \\
\hline \multirow{2}{*}{$\begin{array}{l}\text { Six color } \\
\text { mixed }\end{array}$} & Rapid N III & 240 & 25.53 & 1.85 & 21.03 & 29.69 & 8.66 & 3.41 & 0.12 & 7.24 \\
\hline & NIR DA 7250 & 240 & 34.03 & 1.71 & 28.76 & 37.75 & 8.99 & 2.93 & 0.11 & 5.03 \\
\hline
\end{tabular}




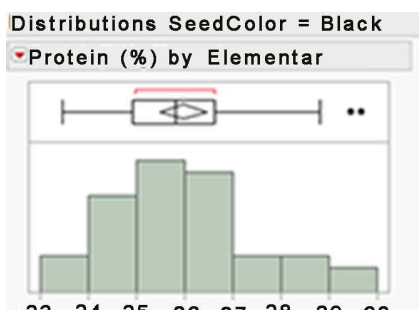

$\begin{array}{llllllll}23 & 24 & 25 & 26 & 27 & 28 & 29 & 30\end{array}$

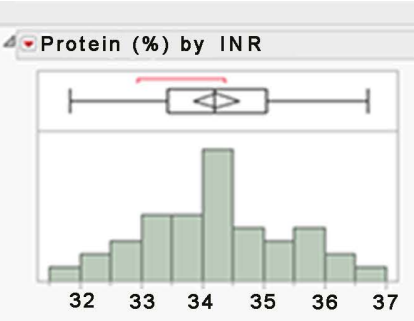

Distributions SeedColor = Blackeye - Protein (\%) by Elementar

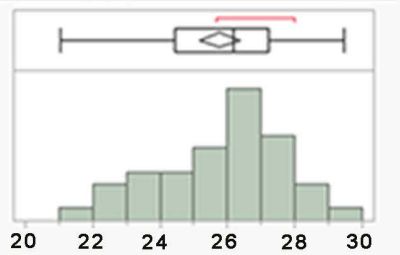

$\triangle$ - Protein (\%) by INR

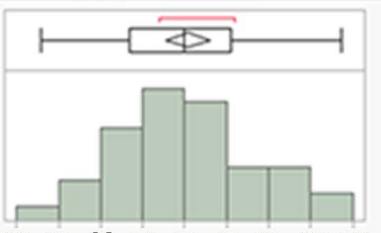

$\begin{array}{lllllllll}30 & 31 & 32 & 33 & 34 & 35 & 36 & 37 & 38\end{array}$

Distributions SeedColor $=$ Browneye -Protein (\%) by Elementar

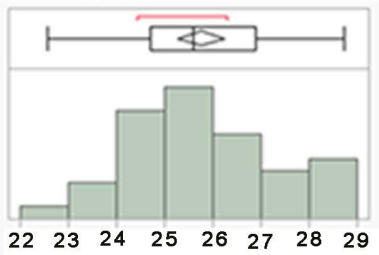

$\triangle-$ Protein (\%) by INR

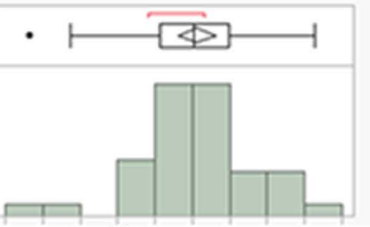

$2930 \quad 3132 \quad 3334 \quad 35 \quad 36 \quad 3738$
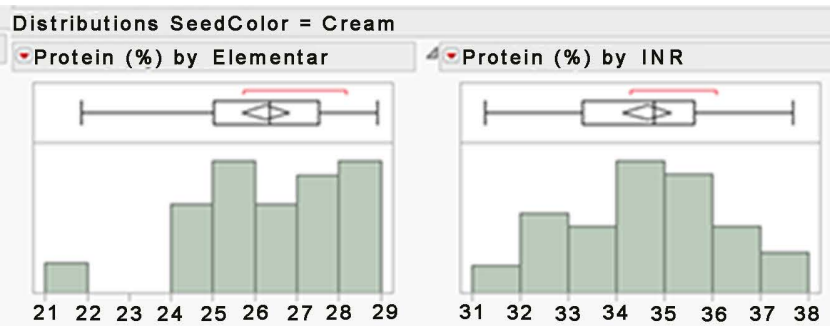

Distributions SeedColor $=$ Pinkeye

- Protein (\%) by Elementar
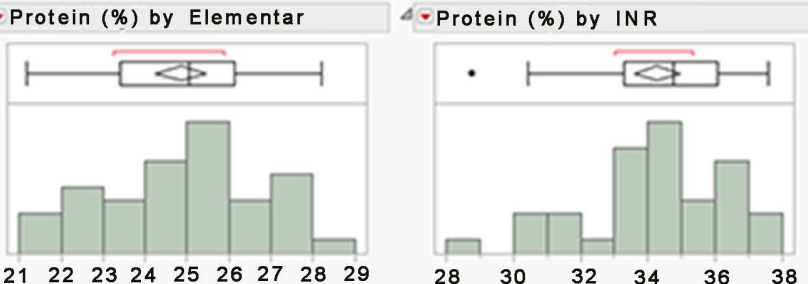

Distributions SeedColor $=$ Red

- Protein (\%) by Elementar

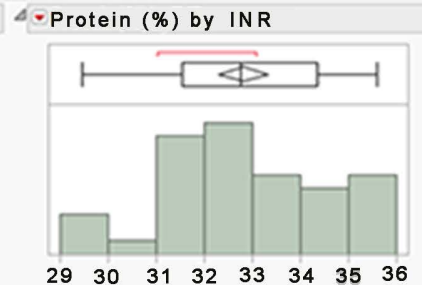

Figure 2. Distributions of seed protein (\%) of six seed coat colors: black seed, blackeye seed, browneye seed, cream seed, pinkeye seed, and red seed measured by two methods with NIR DA 7250 [Protein (\%) by NIR] and by Rapid N III [Protein (\%) by Elementar] among 40 cowpea genotypes, respectively.

from $21.03 \%$ to $29.69 \%$ and averaged $25.53 \%$ for protein by Rapid N III and ranged from $28.76 \%$ to $37.75 \%$ with an average of $34.03 \%$ by NIR (Table 1), indicating the cowpea seed protein content had large variation among 240 cowpea genotypes regardless of the analytical methods. The wide diversity of cowpea seed color was categorized into six groups with black, blackeye, browneye, cream, pinkeye, and red color in this study. The mean, standard deviation (Std Dev), maximum, minimum, range, variance, standard error (Std Err), and coefficient of variation (CV)among the six different color groups were estimated (Table 1). Most of distributions of seed protein (\%) of six seed coat colors measured by two methods with NIR DA 7250 [Protein (\%) by NIR] and by Rapid N III [Protein (\%) by Elementar] among 40 cowpea genotypes showed a near normal with a large range great than $6 \%$ (Figure 2, Table 1), indicating the 40 samples in each seed color was an random sample with a large range and a big variance.

It is observed that the NIR method gave higher seed protein content than that from the Rapid $\mathrm{N}$ method in each of the six different color groups (Table 1, Figure 2 and Figure 3). Because it has more sensitive to different wavelengths from the range of colors of the cowpea seed, the NIR method gives higher seed protein content which is higher than real protein content in cowpea seeds, which is caused by the NIR analyzer. Although protein content measured by NIR DA 7250 had higher content than those by Rapid N III, the trend of seed protein 


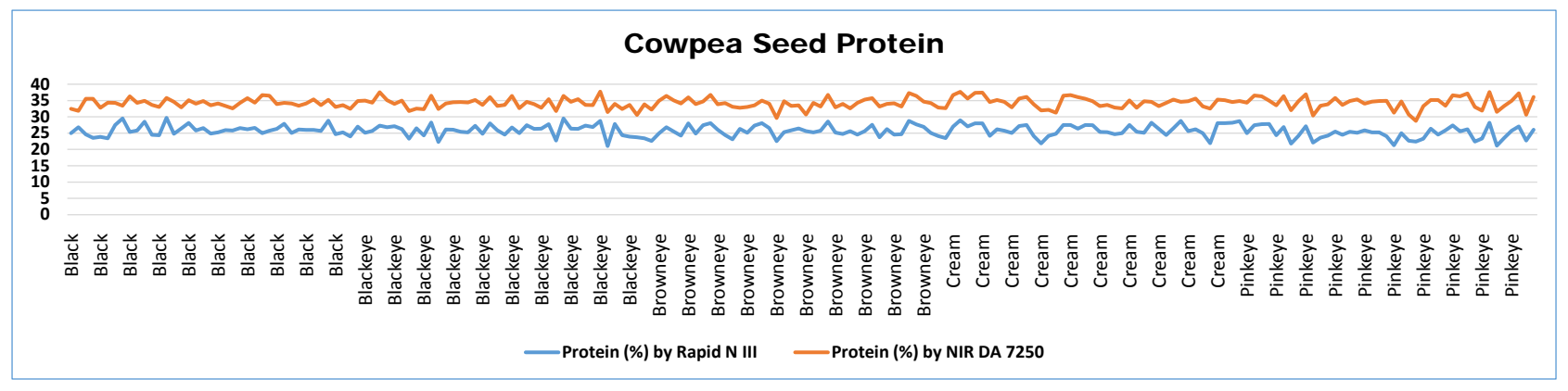

Figure 3. Cowpea seed protein content (\%) by NIR DA 7250 and by rapid N III.

content in each of the six seed color showed same among the 40 samples (Figure 3 ), indicating the value of seed protein content measured by NIR can be adjusted by Rapid $\mathrm{N}$ with a regression model.

A regression model between the two methods for each of the six seed colors was postulated from this research. Although protein content measured by NIR DA 7250 expressed higher than that by Rapid N III, the correlation between the two methods was strong with an high correlation coefficient (r) value of 0.690 combined all genotypes of the six seed colors. Different $r$ values among the six color groups were observed (Table 2). The r values of pinkeye, blackeye, cream, and browneye color cowpea were very high, measured at $0.867,0.771,0.729$ and 0.700 , respectively. The strong correlation between the two methods for the pinkeye, blackeye, cream, and browneye color cowpea provides us to adjust a protein content value from NIR analyzer to a closer real protein value from Rapid N method through a linear regression model. But black seeded cowpea had a very low $r$ value with 0.184 , indicating that the NIR method is not suitable for cowpea seeds with black or dark color coat. As the red seeds, a mediate $r$ value with 0.623 was estimated (Table 2, Figure 4), indicating we may use the NIR method to measure the protein content in red cowpea seeds.

In this study, a linear regression $\mathrm{Y}=\mathrm{aX}+\mathrm{b}$ was postulated for each color (Table 2, Figure 4), in which " $a$ " is the slope of the line and " $b$ " is the intercept on the ordinate. If " $b$ " is close to 1 and " $a$ " close to zero, the two methods provide similar results. Because there were different $r$ values between the two methods for each seed color, we developed separately linear regression model for each seed color and a total of six models were created for the six texted seed colors (Table 2, Figure 4). From Figure 2, five colors except black seeds fit a linear relationship from the distributions (Figure 4). From Table 2, we can see the " $b$ " values are greater than 0.75 for blackeye, cream, pinkeye and red, close to 0.7 for browneye but less than 0.24 for black seed, indicating we can use the linear regression model to transfer each protein content value by NIR (X) to protein content value (Y) for five seed colors except black seeds. Therefore, the protein content in cowpea seeds can be directly measured by NIR analyzer as a fast measuring method.

In addition to good measurement data, the two methods have their own characteristics. Both near infrared Reflectance and Rapid $\mathrm{N}$ approaches were 
Table 2. The correlation coefficient ( $\mathrm{r}$ ) and regression model between the two measurement methods among six seed coat colors.

\begin{tabular}{cccc}
\hline Seed Coat Color & Samples & Correlation Coefficient $(\mathbf{r})$ & Equation \\
Black & 40 & 0.184 & $\mathrm{Y}=0.239 \mathrm{X}+17.78$ \\
Blackeye & 40 & 0.771 & $\mathrm{Y}=0.893 \mathrm{X}-4.66$ \\
Browneye & 40 & 0.700 & $\mathrm{Y}=0.689 \mathrm{X}+2.26$ \\
Cream & 40 & 0.729 & $\mathrm{Y}=0.811 \mathrm{X}-1.85$ \\
Pinkeye & 40 & 0.867 & $\mathrm{Y}=0.774 \mathrm{X}-1.67$ \\
Red & 40 & 0.623 & $\mathrm{Y}=0.755 \mathrm{X}-0.19$ \\
Six color merged & 240 & 0.690 & $\mathrm{Y}=0.744 \mathrm{X}+0.20$ \\
\hline
\end{tabular}
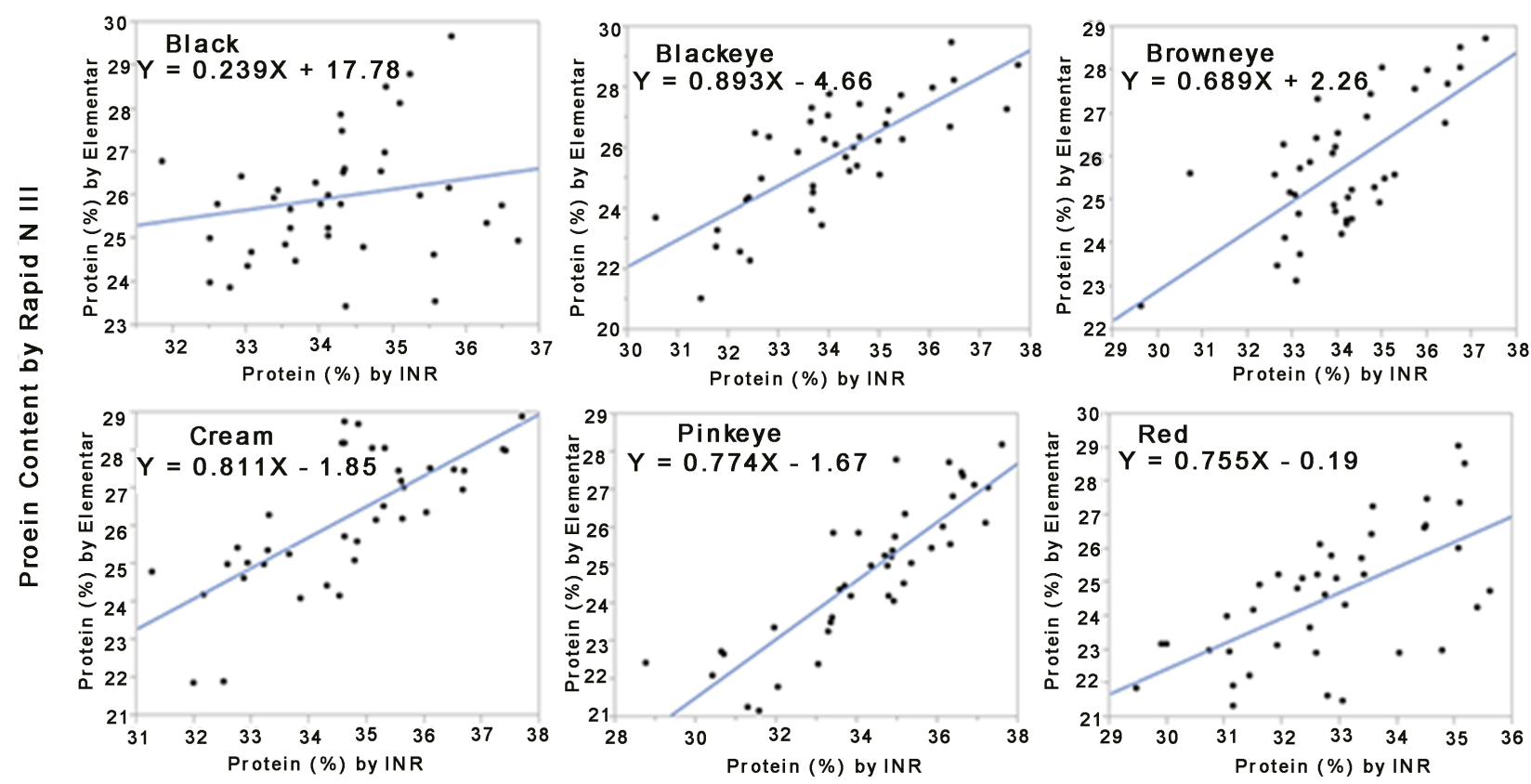

Protein Content by NIR DA 7250

Figure 4. The correlation coefficient ( $\mathrm{r}$ ) and regression model between the two measuring methods among six seed coat colors.

comparable in accuracy and reproducibility for measuring cowpea seed protein contents. Rapid $\mathrm{N}$ takes analytical technology to protein concentration measurement through nitrogen/protein analyzer according to the principle of catalytic tube combustion in an oxygenated $\mathrm{CO}_{2}$ atmosphere and high temperatures. It represents the fast, safe and environmentally friendly alternative to the classical Kjeldahl method. However, comparing with NIR, it looks more time to grand the seeds to powder and it costs (Table 3). NIR analyzer is an easier, faster, more economic, and non-damaging method to measure protein content in cowpea seeds. Therefore NIR analyzer method has been recommended to be directly used in measuring protein content in cowpea seeds with five seed colors of blackeye, browneye, pinkeye, cream and red seeds and through a linear regression model each color, the protein content value from NIR analyzer can be 
Table 3. The comparison of two methods for seed protein content measurement.

\begin{tabular}{ccc}
\hline Comparison Method & NIR DA7250 & Rapid N III \\
Sample type & Whole grain & Grind flour \\
Amount & $100 \mathrm{~g}$ & $0.10-0.15 \mathrm{~g}$ \\
Sample & No-preparation & Preparation \\
Speed & $6-10 \mathrm{sec} /$ sample & $2-4$ min/ sample \\
Damage & Whole grain, no damage & Seeds grind, damage \\
Date analysis & Regression line & Adjust by conversion factor of 6.25 \\
\hline
\end{tabular}

adjusted to a correct value. However, the dark color cowpea seeds (black) are not suitable for seeds protein content measurement by NIR.

\section{Conclusion}

From this study, the protein content in cowpea seeds had a big variation from both methods among the tested 40 cowpea genotypes in each of the six seed color groups (Table 1, Figure 1 and Figure 2), but the NIR analyzer gave a greater value than the Rapid N III (Table 1 and Figure 3). However, a strong correlation was observed between the two methods with a high correlation coefficient among five seed colors of blackeye, browneye, pinkeye, cream and red except black seeds. The correlation efficiencies ( $\mathrm{r}$ ) between the two methods are 0.867, $0.771,0.729,0.700$, and 0.623 for pinkeye, blackeye, cream, browneye, and red, respectively, indicating that NIR analyzer can be used to measure protein content for cowpea seeds with the five types of seed coat, excepting black color seeds $(r=0.184)$ (Table 2). The linear regression model was built to adjust to seed protein content from cowpea seeds for each of five seed color groups, respectively when NIR analyzer DA 7250 are applied (Table 2, Figure 4) in order to obtain the accurate seed protein content in different color type, thus provides a reliable and fast method to measure seed protein content in cowpea seeds using NIR analyzer. In additions, the NIR analyzer should be a better method to measure the protein content as whole grain in cowpea seeds without destruction and also it is a low-cost method and easy to operate in lab (Table 3). Therefore, it has great promise to be adopted as a rapid performed method to measure seed protein content for cowpea breeding program to improve protein contention.

\section{References}

[1] Carnovale, E., Marletta, L., Marconi, E. and Brosio, E. (1990) Nutritional and Hydration Properties in Cowpeas. In: Ng, N.Q. and Monti, L.M., Eds., Cowpea Genetic Resources, International Institute of Tropical Agriculture (IITA), Ibadan, 111-118.

[2] Pedalino, M., Paino D’urzo, M., Costa, A., Grillo, S. and Rao, R. (1990) Biochemical Characterization of Cowpea Seed Proteins. In: Ng, N.Q. and Monti, L.M., Eds., Cowpea Genetic Resources. Contributions in Cowpea Exploration, Evaluation and Research from Italy and the International Institute of Tropical Agriculture; Meeting, Ibadan, Nigeria, February 6-7. Vii 200 p. International Institute of Tropical 
Agriculture, Ibadan, 81-89.

[3] Singh, B.B, Ajeigbe, H., Tarawali, S., Fernandez-Rivera, S. and Abubakar, M. (2003) Improving the Production and Utilization of Cowpea as Food and Fodder. Field Crops Research, 84, 169-177. https://doi.org/10.1016/S0378-4290(03)00148-5

[4] Okonya, J.S. and Maass, B.L. (2014) Protein and Iron Composition of Cowpea Leaves: An Evaluation of Six Cowpea Varieties Grown in Eastern Africa. African Journal of Food, Agriculture, Nutrition and Development, 14, 2129-2140.

[5] Gupta, P., Singh, R. and Malhotra, S. (2014) Cowpea (Vigna unguiculata (L.) Walp) Seed Proteins: Heterogeneity in Total Proteins and Protein Fractions. Legume Research, 37, 62-67. https://doi.org/10.5958/j.0976-0571.37.1.009

[6] Ravelombola, W., Shi, A., Weng, Y., Motes, D. and Wingfield, C. (2016) Evaluation of Total Seed Protein Content in Eleven Arkansas Cowpea Genotypes. American Journal of Plant Sciences, 7, 2288-2296. https://doi.org/10.4236/ajps.2016.715201

[7] Santos, C.A.F., da Costa, D.C.C., da Silva, W.R. and Boiteux, L.S. (2012) Genetic Analysis of Total Seed Protein Content in Two Cowpea Crosses. Crop Science, 52, 2501-2506. https://doi.org/10.2135/cropsci2011.12.0632

[8] Abizari, A.R, Pilime, N., Armar-Klemesu, M. and Brouwer, I.D. (2013) Cowpeas in Northern Ghana and the Factors That Predict Caregivers' Intention to Give Them to Schoolchildren. PLoS One, 8, e72087.

https://doi.org/10.1371/journal.pone.0072087

[9] Boukar, O., Massawe, F., Muranaka, S., Franco, J., Maziya-Dixon, B., Singh, B. and Fatokun, C. (2011) Evaluation of Cowpea Germplasm Lines for Protein and Mineral Concentrations in Grains. Plant Genetic Resources, 9, 515-522. https://doi.org/10.1017/S1479262111000815

[10] Phillips, R.D., Mcwatters, K.H., Chinnan, M.S., et al. (2003) Utilization of Cowpeas for Human Food. Field Crops Research, 82, 193-213. https://doi.org/10.1016/S0378-4290(03)00038-8

[11] Itatat, S.L., Nworgu, E.C., Ikpe, E.N. and Osakwe, J.A. (2013) Evaluation of the Protein Contents of Selected Cowpea (Vigna unguiculata (L.) Walp.) Varieties for Production in Port Harcourt. Acta Agronomica Nigeriana, 13, 71-75.

[12] Afiukwa, C.A., Ubi, B., Kunert, K., Titus, E. and Akusu, J. (2013) Seed Protein Content Variation in Cowpea Genotypes. World Journal of Agricultural Sciences, 1094-1099.

[13] Moore, J.C., DeVries, J.W., Lipp, M., Griffiths, J.C. and Abernethy, D.R. (2010) Total Protein Methods and Their Potential Utility to Reduce the Risk of Food Protein Adulteration. Comprehensive Reviews in Food Science and Food Safety, 9, 330-357. https://doi.org/10.1111/j.1541-4337.2010.00114.x

[14] Kjeldahl, J. (1883) Neue Methode zur Bestimmung des Stickstoffs in organischen Körpern. [New Method for the Determination of Nitrogen in Organic Substances.] Zeitschrift für analytische Chemie, 22, 366-383. https://doi.org/10.1007/BF01338151

[15] Williams, P.C. and Sobering, D.C. (1993) Comparison of Commercial near Infrared Reflectance and Reflectance Instruments for Analysis of Whole Grains and Seeds. Journal of Near Infrared Spectroscopy, 1, 25-32. https://doi.org/10.1255/jnirs.3

[16] Lubran, M.M. (1982) Comparison of Two Methods of Measurement of the Same Substance: An Evaluation of Some Statistical Procedure Annals of Clinical and Laboratory Science, 12, 134-142. 
Submit or recommend next manuscript to SCIRP and we will provide best service for you:

Accepting pre-submission inquiries through Email, Facebook, LinkedIn, Twitter, etc. A wide selection of journals (inclusive of 9 subjects, more than 200 journals)

Providing 24-hour high-quality service

User-friendly online submission system

Fair and swift peer-review system

Efficient typesetting and proofreading procedure

Display of the result of downloads and visits, as well as the number of cited articles Maximum dissemination of your research work

Submit your manuscript at: http://papersubmission.scirp.org/

Or contact ajps@scirp.org 